\title{
RDA - a change of vision
}

\author{
Victoria Frâncu \\ $\mathrm{PhD}$ \\ E-mail v_francu@yahoo.com
}

This paper takes a look at the evolution of the cataloging rules, and aims at highlighting what is preserved and what is changed in the way progress was made. It points out the need of innovative rules and features for the bibliographic description and access, so that they agree with the requirements of the new information resources, the new library user profile and information needs. Bibliographic control is also considered and more so, the characteristics of library science education are looked at, particularly in the manner they come to an agreement with the new RDA rules, or change of vision.

Keywords: $\quad$ library catalogues, cataloging rules, cataloging principles, bibliographic control, RDA rules, library science education

\section{Introduction}

Resource Description and Access (RDA) is a set of descriptive cataloging rules meant to replace the well-known Anglo-American Cataloging Rules-2 (AACR2), used for a very long time by many libraries in the United States and in libraries throughout the world just as well. According to Shawne Miksa (2009), the distance in time between AACR2, first released in 1978, and this new set of cataloging rules has necessarily to go through an appropriate understanding of other significant concepts found in Functional Requirements for Bibliographic Records - FRBR (1998) and Functional Requirements for Authority Data - FRAD (2009). The conceptual models described and analyzed in these two documents developed by special interest groups within the International Federation of Library Associations (IFLA) are of utmost importance for a good knowledge of RDA.

However, a close look at how the first cataloging rules were formulated more than a century ago by the famous Charles A. Cutter (1904), will demonstrate the legitimacy of his thinking. The objectives of a library catalogue according to Cutter and the principles of cataloging established by the works of Panizzi and Lubetzky are found at the basis of the two conceptual models mentioned above. To those who know, let alone to those who apply them, FRBR and FRAD form, as Miksa calls it, "the backbone of RDA".

All these being said, we shall see in the ongoing how the RDA rules have emerged, having as sources the thinking of prominent forerunners, with some amendments in order to fit the needs of the current information seeker.

\section{From Charles A. Cutter, onwards}

In order to show the importance of rules in designing a library catalogue, Cutter (1904) highlights the rationale of the twofold interest of the cataloger: the convenience of the library user, so that he can easily find what he is searching for, but also the respect of rules resulting from "experience and good judgment". Cutter says: "The convenience of the public is always to be set before the ease of the cataloger. [...] Cataloging is an art, not a science. . No rules can take the place of experience and good judgment, but some of the results of experience may be best indicated by rules" (Cutter 1904).

Revista Română de Biblioteconomie şi Ştiința Informării = Romanian Journal of Library and Information Science ISSN 2559-5490, ISSN-L 1841-1940 • Volume 16 Issue 12020 pp. 22-29 https://doi.org/10.26660/rrbsi.2020.16.1.22

This work is licensed under a Creative Commons Attribution-NonCommercial-NoDerivatives 4.0 International License 
Mention should be made on the fact that Cutter's Rules emerged from a list he made of the users' inquiries regarding, among other things: the kind of binding, book publisher, suitability for different age groups, particular forms of literature and even color and size (Miksa 1974).

The objectives of a library catalogue formulated by Cutter at the end of the $19^{\text {th }}$ century, as most of the members of the cataloging community may know, comprise three categories of basic principles which have generally been followed by library catalogue designers ever since.

1. To enable a person to find a book of which either

(A) the author

(B) the title is known

(C) the subject

2. To show what the library has

(D) by a given author

(E) on a given subject

(F) in a given kind of literature

3. To assist in the choice of a book

(G) as to its edition (bibliographically)

$(\mathrm{H})$ as to its character (literary or topical)

Cutter's objectives correspond to three basic principles: a) the finding principle, enabling the user to identify individual books so they can be located effectively as unique items, b) the gathering principle, i.e. classifying or grouping the uniquely identified books into categories required by users and c) the evaluating principle, supplying bibliographic information that would enable users to choose a book starting from the catalogue entry itself (Miksa 1974). We shall go back to these principles later in this paper.

The ideal catalogue, according to Cutter's Rules, should give under each subject its complete bibliography, not only mention every monograph on that particular subject, but also all the works that deal with that subject, including fragments from books, articles from magazines and the best encyclopedias that deal with that.

\section{The landmarks set by Panizzi, Cutter and Lubetzky to FRBR}

In order to demonstrate both the demands of the contemporary library user and the requirements of the library catalogs today, William Denton (2007) describes an experiment. He tells the story of Brigid, who has seen the movie "The Big Sleep" and wanted to borrow from the library the book on which this is based. She found the book at her library, but it was lent out. Then she made another search and found it in more libraries, of which one had three copies. She ordered one of those. She wanted any edition of "The Big Sleep", written in English and not in large print, neither did she want an audio book, just a regular one. But the system of that library asked her to get connected with a certain copy of the book, hard cover, dated 1973 and held by their branch in Alexandria Street. She ordered it and received it in a couple of days.

If that library had a FRBR-based catalogue, it would have been more helpful to her. She would have found the work, then the expressions, the manifestations, enabling her to choose what she wanted, and then the items held. Furthermore, if that library had a web-based FRBR catalog, as Denton argues, Brigid would search for a work: The Big Sleep and get a list containing the 1939 book and the film adaptations from 1946 and 1978. The author, Raymond Chandler is a person, so Brigid could choose his name as a hyperlink, and get a list of works created by him. Chandler is also a subject, so she could get several biographies about him and he would be included in any American (place) book on fiction (concept), or mystery (concept), in a work (concept) from the 20th century (event). All entities - works, expressions, subjects, places, concepts - would be intertwined in a complicated network of connections.

In the mentioned study about FRBR and the history of cataloging, William Denton observes the similarities between the fundamental cataloging principles formulated by Cutter, Panizzi and Lubetzky and this conceptual model. 
The IFLA's Final Report on FRBR (1998) mentions four generic tasks for the library user, which obviously correspond significantly to Panizzi, Cutter and Lubetzky's principles and rules. Here they are:

to find materials that correspond to the user's stated search criteria (e.g., in the context of a search for all documents on a given subject, or a search for a recording issued under a particular title);

to identify an entity (e.g., to confirm that the document described in a record corresponds to the document sought by the user, or to distinguish between two texts or recordings that have the same title);

to select an entity that is appropriate to the user's needs (e.g., to select a text in a language the user understands, or to choose a version of a computer program that is compatible with the hardware and operating system available to the user);

to obtain access to the entity described (e.g., to place a purchase order for a publication, to submit a request for the loan of a copy of a book in a library's collection, or to access online an electronic document stored on a remote computer).

Going back to Denton's demonstration, we see that Brigid's search for the book on which the film she saw was based fits perfectly into these requirements. She was looking for a book of which she knew the title, she wanted it to be written in English, but preferably not in large print, she didn't want an audio book; then she placed a request for an interlibrary loan resulting from these selection criteria and borrowed a copy of that book.

It is easy to notice, as Denton did, the correspondence between the FRBR user's tasks and the fundamental cataloging rules, despite the great difference in time when their creators lived. There have been successive sets of rules meant to establish order in the bibliographic elements represented in a catalogue beginning as early as the middle of the $19^{\text {th }}$ century. Denton mentions the merits of Antony Panizzy while he pays high respect to the complexity, "broad knowledge, keen thinking, and fruitful imagination which the founders of the rules have brought to the profession of cataloging"(Denton 2007). Many subsequent avatars of the main cataloging rules followed and gained in intricacy but also in usefulness, their content being permanently adapted to new requirements as to the current users' demands and the innovative technology's high standards. The list below is given by Denton to show the association he made between the functions, objectives and principles of cataloging as established by the historical personalities of the field and the FRBR conceptual structure.

- $\quad$ the relationship work-author groups all the works of an author - found in Lubetzky;

- all the editions, translations, adaptations, of a work are clearly separated (as expressions and manifestations) - found in Lubetzky;

- all the expressions and manifestations of a work are collocated with their related works in bibliographic families;

- $\quad$ any document (manifestation or item) can be found if the author, title or subject of that document is known - found in Cutter;

- $\quad$ the author is authorized by the authority control;

- the title is an intrinsic part of the work + authority control entity.

Denton defines Lubetzky's principles to be inspiring for the FRBR model. In so doing, he highlights the authority control function of the catalogue which is essential for finding a work by the author-title search key. Through the collocating function, rather than the finding function, with the addition of all kinds of relationships the model has a provision for, entities are clustered according to their common elements in bibliographic families (Le Boeuf 2001, Tillett 2002, Frâncu 2004). 
The main condition for this to happen is a good search facility of the library system. An important objective of the conceptual model was to integrate heterogeneous resources in the online library catalogues, as it resulted from the ELAG (European Library Automation Group is Europe's premier conference on the application of information technology in libraries and documentation centers) conference on practical experimentation of FRBR.

\section{FRAD (Functional Requirements for Authority Data) as an extension of FRBR}

The multiple and complicated network of relationships among the bibliographic entities in the FRBR conceptual model required a set of guidelines for the management of authority data. A new conceptual model was created for this purpose, Functional Requirements for Authority Data (FRAD, 2009). This was drafted by IFLA's Working Group on Functional Requirements and Numbering of Authority Records (FRANAR), established in 1999.

The FRAD model contains an analysis of attributes belonging to entities of major interest for authority data (persons, families, corporate bodies, works, expressions, manifestations, items, concepts, objects, events and places), the name by which these entities are known and the controlled access points created for them. The conceptual model describes not only the attributes of these entities but also the relationships between them.

The purpose of FRAD conceptual model is "to provide a framework for the analysis of functional requirements for the kind of authority data that is required to support authority control and for the international sharing of authority data" (FRAD, 2009). In other words, FRAD's objectives are to create a model for the description of authority data and to relate this model with the needs of the library users aiming at the international exchange of authority data.

\section{Cataloging as a communication process}

An important statement was made by Shawne Miksa at the American Library Association Annual Conference: Heads of Cataloging Interest Group in 2010. She said that both the bibliographic control and the role of a cataloger have to be reconsidered. The cataloger, according to her statement, "is not just a transcriber, but an information translator" (Miksa, 2010). Additionally, she said that "cataloging is a communication process".

In order that a communication process take place, at least three factors are necessary: a sender, a message being sent and a receiver (Bühler, 1990). Roman Jakobson (1960) was inspired by Bühler's Sprachtheorie in formulating his theory of verbal communication, in which there are six factors involved: (1) a context (the other verbal signs in the same message, and the world in which the message takes place), (2) an addresser (a sender), (3) an addressee (a receiver), (4) a contact between an addresser and addressee, (5) a common code and (6) a message.

The indexing languages, like the natural languages, play the same role in information transfer as the latter do in verbal communication. They work as a code in which the message is expressed in order to reach from the sender (the indexer) to the receiver (the user), once the contact between the two has been established. The meaning of a descriptor or another indexing language element is dictated by the context, with a role in the semantic disambiguation of the indexing language terms. The semantic relations, also, either hierarchical or associative have much to say about the meaning of an indexing term (Frâncu 2003).

The communication process which takes place during cataloging involves four factors, too, according to Miksa. In the diagram she draws, the cataloger takes the central position, a place where three circles meet: the users, the information resources and the library systems. This process takes in, apart from the mentioned factors, the complex entity-relation (E-R) models of FRBR, in which the information resources considered are Works, Manifestations, Expressions and Items (WEMI). The meanings, functions and attributes of these entities have to be thoroughly known and therefore worked with in a regular manner. The library catalogue will aggregate bibliographic records based on the E-R conceptual model of FRBR (WEMI, relations and user tasks) and FRAD (the same entities within the authority control frame). Given these 
circumstances, the catalogue becomes a relational database in which representations of information resources are dealt with. The cataloger's task is the creation and representation of the information resources, continuously governing these representations.

\section{RDA (Resource Description and Access) and its functionalities}

From the point of view of the present-day information searcher, the functionalities of the library catalogue are somehow outdated and minimized, the priority being granted to the search engines in the internet. However, it has been proved more often than not, that the search results are not restricted to bibliographic information, they are far from being structured and are rather redundant (Miksa, 2009, Francu, 2017). Even in Google searches, but then with library search tools, like the UDC, the results are better than those using free text Google search.

e.g. Google search performed with UDC notation 58(084.4) - Atlas of botany, as query, gives

75 results, mostly from library catalogues

Google search performed with free text "atlas of botany" as query, gives far more results, but many of them irrelevant (including literature lists, decoration of restaurants, guidelines for home-schooling etc.)

Like all new cataloging rules formerly introduced in libraries, RDA generates some enthusiasm, but also not so convenient feelings. Never-the-less, their advantages are obvious under the current circumstances of a tremendous number of diversified information resources and the persistent need to structure and link them for a better and more accurate usage.

RDA was launched in 2010 as a database product which incorporates specific characteristics and functionalities aiming to attend the online access. RDA is basically incorporating the two conceptual models FRBR (Functional Requirements for Bibliographic Records) and FRAD (Functional Requirements for Authority Data) in a single standard.

Riva \& Oliver (2012) explain and demonstrate the alignment between FRBR, FRAD and RDA regarding their entities, attributes, relations and user functions. RDA is a descriptive cataloging standard and successor of the AACR2 cataloging rules. It operates with authorized access points and no longer with main headings and auxiliary headings. In so doing it is motivated by several factors such as:

the changes in technology strongly impacting the descriptive and access data (book catalogues, card catalogues, OPAC's);

the transition from the individual isolated libraries to incorporated large libraries with international audience;

the transition from classes of library materials to elements and values (controlled vocabularies).

Created according to the IFLA Statement of International Cataloguing Principles, RDA observes the Principles of Paris and is based on the great cataloging traditions of the world plus FRBR and FRAD. At the same time RDA permits a more granular approach to the information resources represented in the catalogue. Intended to describe all types of resources (not only books), RDA allows the representation of bibliographic relations and mediates the access to bibliographic and authority records (not only the selection and the form of the entries).

Looking at the time when the discussions about the new cataloging rules have started, it is easy to notice how big the demand of those rules was. For longer than ten years, the number of other types of resources, such as digital objects, websites, events and a lot more grow over the printed matter in the total amount of library material, the RDA set of rules are just the right response to their appropriate management. Their attributes and the relationships between them, such as entities and their titles, authors - personal or corporate bodies - plus the access points to each of those need a thoroughly different approach from what was known from the printed environment times. Miksa (2009) makes a useful analysis of the RDA rules and recommends a list of literature for their comprehensive study and implementation issues. Additionally, for a better understanding of the differences between the two sets of rules, she includes a comparison between AACR2 and RDA. 


\section{Objectives for library system suppliers, authority control and library education}

Given the new cataloging standard it goes without saying that the library system providers have also to take into account the reconfiguration of their systems, in order to incorporate the new functionalities required by the accurate representation of bibliographic and authority data. Responsiveness to the user needs, along with the catalogers' demands, is an utmost important vector to be taken into consideration for the reconfiguration of library systems. That is why authority control has to be improved, expanded and differentiated according to the new requirements enacted by the RDA set of cataloging rules.

The profile of library education has to be changed according to the innovative RDA rules, based of the FRBR and FRAD conceptual models. The endless study of the main and auxiliary headings has to be stopped and just reminded of as historical stage in the cataloging techniques.

Library education, as much as the continuous education for library professionals are both major objectives and high priorities. Having a hectic time with data management, today's librarian is becoming a data scientist and/or a library and information worker who has to learn, among other things, programming.

\section{Note}

This article is based on a paper presented at the National Conference of the Romanian Library Association - Cataloging, Classification and Indexing Section, Bucharest, 4-6 September, 2019. 


\section{References:}

Le Boeuf, P. (2001). FRBR towards some practical experimentation in ELAG? Available at: https://old.stk.cz/elag2001/Papers/PatrickLe_Boeuf/PatrickLe_Boeuf.html. Accessed 26.05.2020

Bühler, Karl (1990). The Theory of Language: The Representational Function of Language (Sprachtheorie). Amsterdam: John Benjamin's Publishing Company. ISSN 0168-2555,p. 35

Cutter, C. A. (1904). Rules for a Dictionary Catalogue. 4th ed. Washington: Govt. Printing Office. Available at: https://archive.org/details/rulesforadictio06cuttgoog/page/n16. Accessed 9.05.2020

Constantinescu, Nicolaie (2019) Data management for research projects [presentation under the auspices of the Romanian Library Association, in Bucharest, Library of the Academy of Economic Studies, June 20]

Denton, William (2007). FRBR and the History of Cataloguing. In: Understanding FRBR: What It Is and How It will affect our retrieval Tools. Ed. by Arlene Taylor. Available at: https:// www.miskatonic.org/library/frbr.html. Accessed 9.05.2020

Frâncu, V. (2003). Multilingual Access to Information using an Intermediate Language: proefschrift. Antwerpen: Universiteit Antwerpen, 2003, VII, 196 p. Available at: http:// arizona.openrepository.com/arizona/handle/10150/106319. Accessed 27.05.2020

Frâncu, V. (2004). An interpretation of the FRBR model. In: Knowledge Organization and the Global Information Society: Proceedings of the Eight International ISKO Conference, 13-16 July 2004, London, UK. Edited by Ia C. McIlwaine. Würzburg: ERGON Verlag, p. 159-165

Frâncu, V. (2017). Facets in an Analytico-Synthetic Classification and Their Role in Subject Retrieval: paper presented at the IFLA LAC WLIC 2017 Satellite Meeting, West University of Timişoara, Romania, 15-16 August 2017

Functional Requirements for Authority Data - A Conceptual Model (2009). Ed. by Glen E. Patton. Available at: https://www.ifla.org/publications/ifla-series-on-bibliographic-control-34. Accessed 26.05.2020

Functional Requirements for Bibliographic Records (1998). Final Report / IFLA Study Group on the Functional Requirements for Bibliographic Records Available at: https:/www.ifla.org/files/ assets/cataloguing/frbr/frbr.pdf. Accessed 19.05.2020

Goosens, P. (2001). ELAG 2001: report of a library systems seminar on integrating heterogeneous resources. Available at: https:/www.emerald.com/insight/content/ doi $/ 10.1108 / 00330330210447226 /$ full $/ \mathrm{html}$ ?fullSc=1\&fullSc=1\&mbSc=1. Accessed 26.05.2020

Jakobson, Roman (1960). Linguistics and Poetics. In: Sebeok, T. ed., Style in Language, Cambridge, MA: M.I.T. Press

Miksa, Shawne (2009). Resource Description and Access (RDA) and New Research Potentials. Available at: https://www.academia.edu/3037976/

Resource_description_and_access_RDA_and_new_research_potentials?

email_work_card=interaction_paper. Accessed 19.05.2020

Miksa, Shawne (2010). RDA - What cataloging managers need to know. In: American Library Association Annual Conference: Heads of Cataloging Interest Group, 2010, Washington DC. Available at: https://digital.library.unt.edu/ark:/67531/metadc84310/. Accessed 27.05.2020

Miksa, S (1974). Charles Ami Cutter, Systematizer of Libraries. Chapter 6 Cataloging Rules. Available at: https://www.ischool.utexas.edu/ miksa/publications/dissertation/ Charles_Ammi_Cutter-Systematizer_of_Libraries-ch6.pdf. Accessed 16.05.2020 
Riva, P.; Oliver, C. (2012). Evaluation of RDA as an Implementation of FRBR and FRAD. Cataloging \& Classification Quarterly, 50:5-7, 564-586

Tillett, B. B. (2002). The FRBR Model (Functional Requirements for Bibliographic Records): a presentation by Dr. Barbara B. Tillett, June 15, 2002 for ALA ALCTS CCS CC:DA Atlanta, Georgia. Available at: https://slideplayer.com/slide/712065. Accessed 26.05.2020 